\title{
The Purpose of the Ritual Baths in the Tombs of the Kings: A New Proposal
}

\author{
Omri Abadi, Boaz Zissu \\ Bar-Ilan University, Ramat Gan
}

\begin{abstract}
The monumental burial complex known as the "Tombs of the Kings" is regarded by scholars as the burial plot of Queen Helena of Adiabene and her family, who lived in Jerusalem in the first century CE. In this paper we reconsider the original purpose of the two large ritual baths in the burial compound, based on the location of the site relative to its surroundings. The scholarship assumes that ritual baths situated next to tombs were intended for use by participants in funerals or memorial ceremonies. In this paper we suggest that in the case of the Tombs of the Kings, the adjacent baths were meant for purification of pilgrims en route to Jerusalem, as can be understood from their geographical location.
\end{abstract}

Keywords: "Tombs of the Kings," Queen Helena of Adiabene, Jewish ritual baths, Jewish burial, Jewish purification rites, Jewish pilgrimage, Jerusalem topography and geography.

\section{Introduction}

The monumental burial complex known as the "Tombs of the Kings" is believed by scholars to be the burial plot of Queen Helena of Adiabene and her family, who lived in Jerusalem in the first century CE. ${ }^{1}$ This identification is based on the discovery of a sarcophagus with the words Tsadan Malkata incised on it, as well as several references by Josephus to the "monuments of Helena" near the road to Jerusalem from the north (War 5.54-56; 5.147). From the entrance to this burial plot (Figs. 1, 2), located at the present-day corner of Nablus Road (Derekh Shekhem) and Salah a-Din Street, a monumental staircase (Figs. 3, 4) led down to two huge ritual baths (mikwaoth; Figs. $\mathbf{5 , 6 )}$ and to an arched rock-cut gate to the spacious tomb courtyard (Fig. 7). From the courtyard one could see the ornate tomb façade containing the entrance to the burial

1 Kon 1947, 2-9; Kloner - Zissu 2007, 231-234, 611-613. It would be irrelevant to expound here on the identification of the tomb with Queen Helena, although for a different opinion on the subject, see Kokkinos 2015 . 
complex; the underground part consisted of a large entrance chamber and five burial chambers with loculi (kokhim). In the Second Temple period the burial compound may have been right next to one of the main roads to Jerusalem and very close to the city walls.

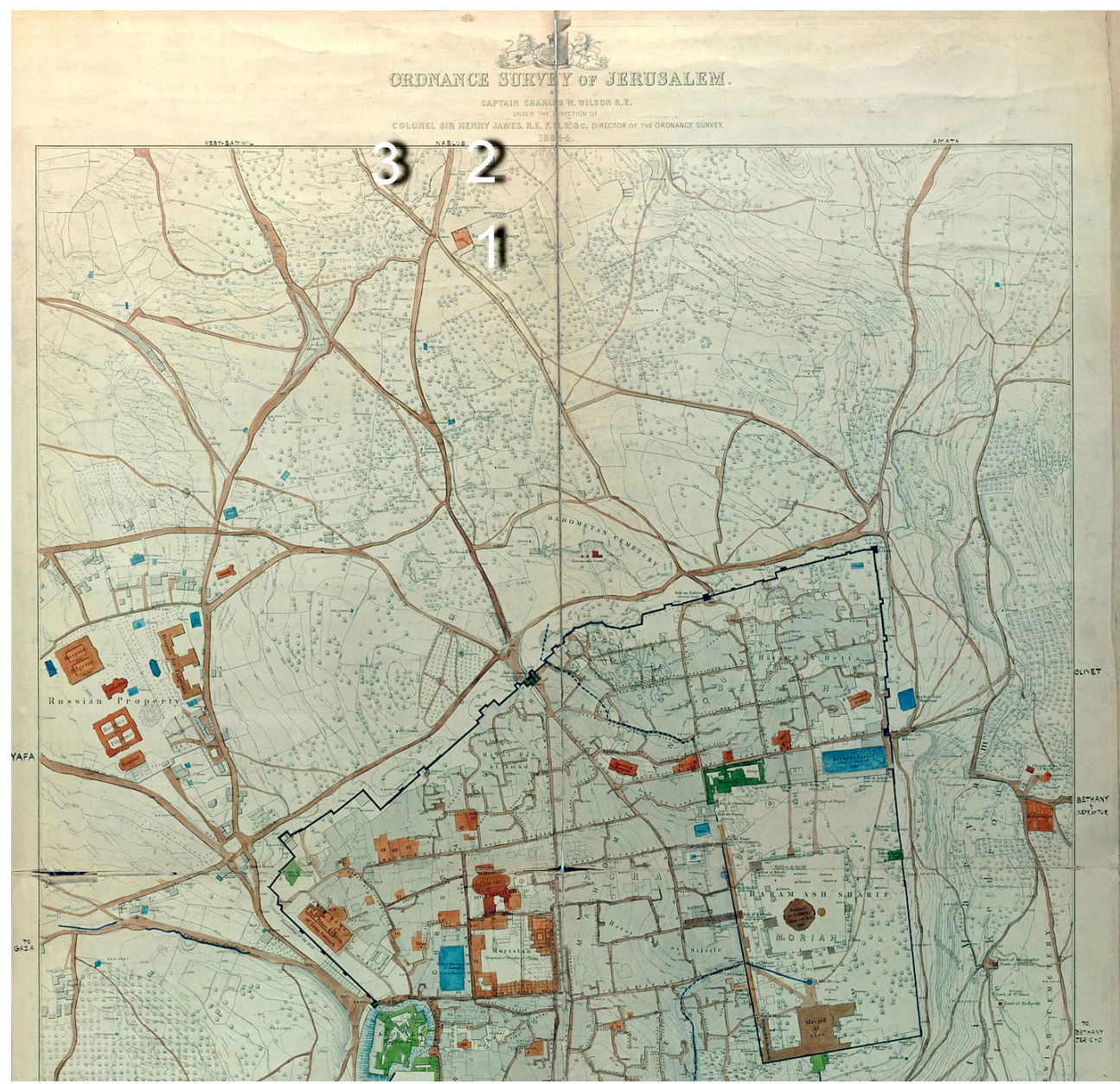

Fig. 1. Location of the Tombs of the Kings (1) near a junction of roads: (2) leads north to Nablus (Schechem / Flavia Neapolis); (3) leads NW and joins road to Neby Samwil (Map of the Ordnance Survey of Jerusalem - by Captain W. Wilson, R.E. under the direction of Colonel Sir Henry James: 1864-5, revised edition 1876) 


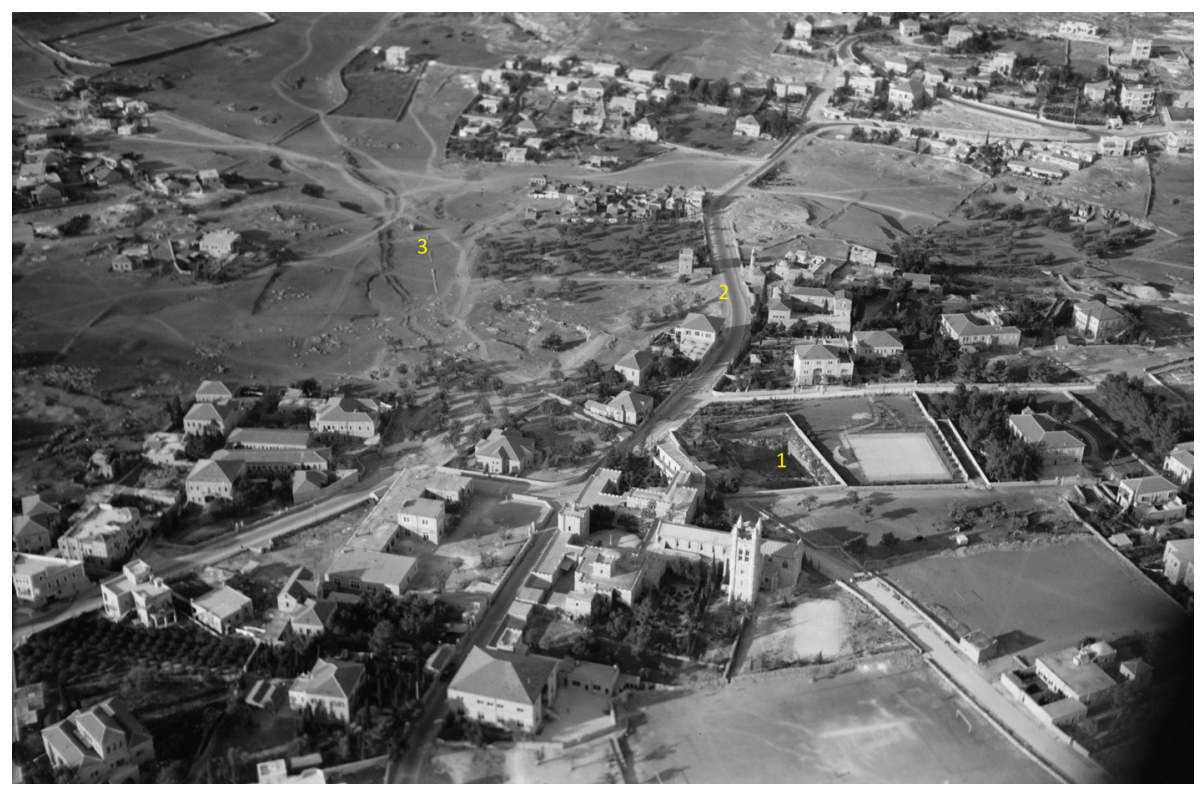

Fig. 2. Oblique aerial photograph of the area north of the Old City of Jerusalem taken on Nov. 10, 1933: Note the Tombs of the Kings (1) adjacent to Nablus road (2) and earlier road to NW (3) marked also in Fig. 1 (Photo by unknown photographer; American Colony (Jerusalem) Photo Dept., Matson

Photograph Collection; Library of Congress, Washington, D.C. LC-DIG-matpc-22157)

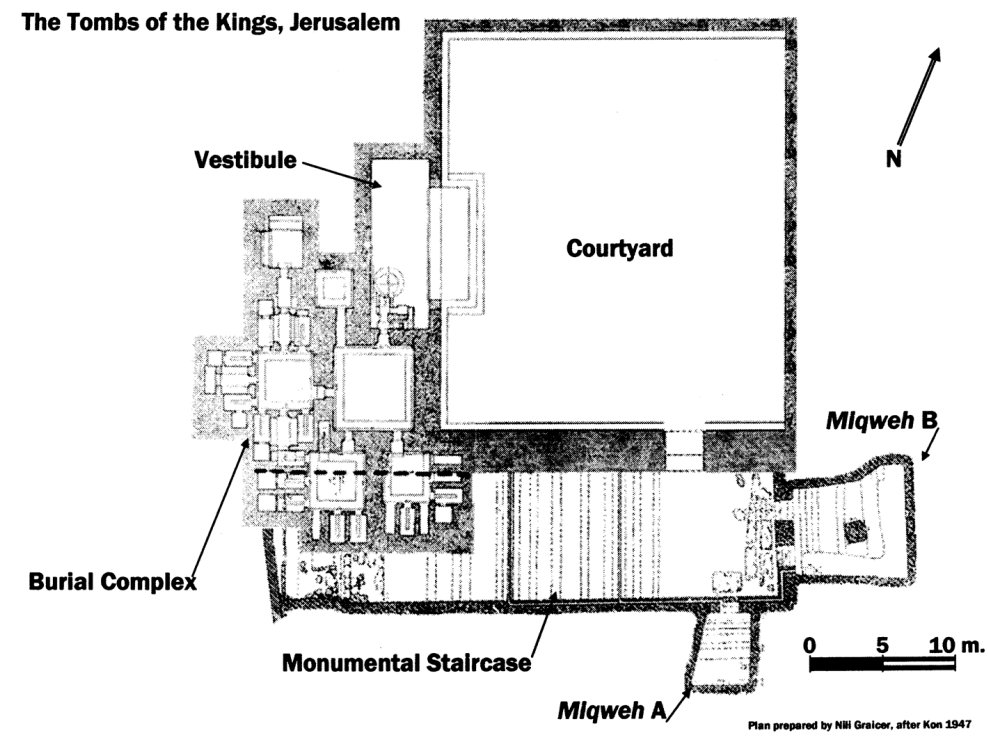

Fig. 3. Plan of the Tombs of the Kings compound. Note the staircase and ritual baths. The smaller installation in the south is Bath A and the larger one in the east is Bath B; note also the separation between the tomb courtyard and the monumental staircase and ritual baths (after Kloner and Zissu 2007; prepared by N. Graicer) 


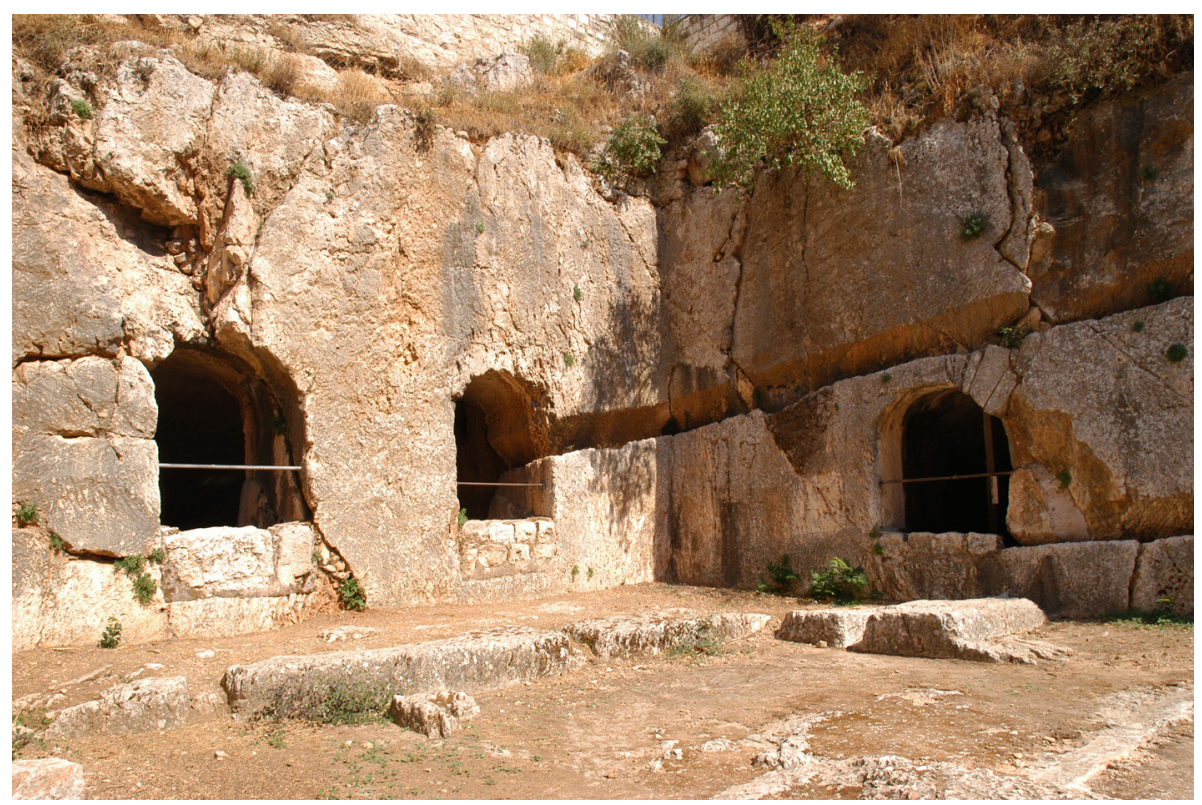

Fig. 4. Openings to ritual baths A and B, looking east (Photo by A. Graicer)

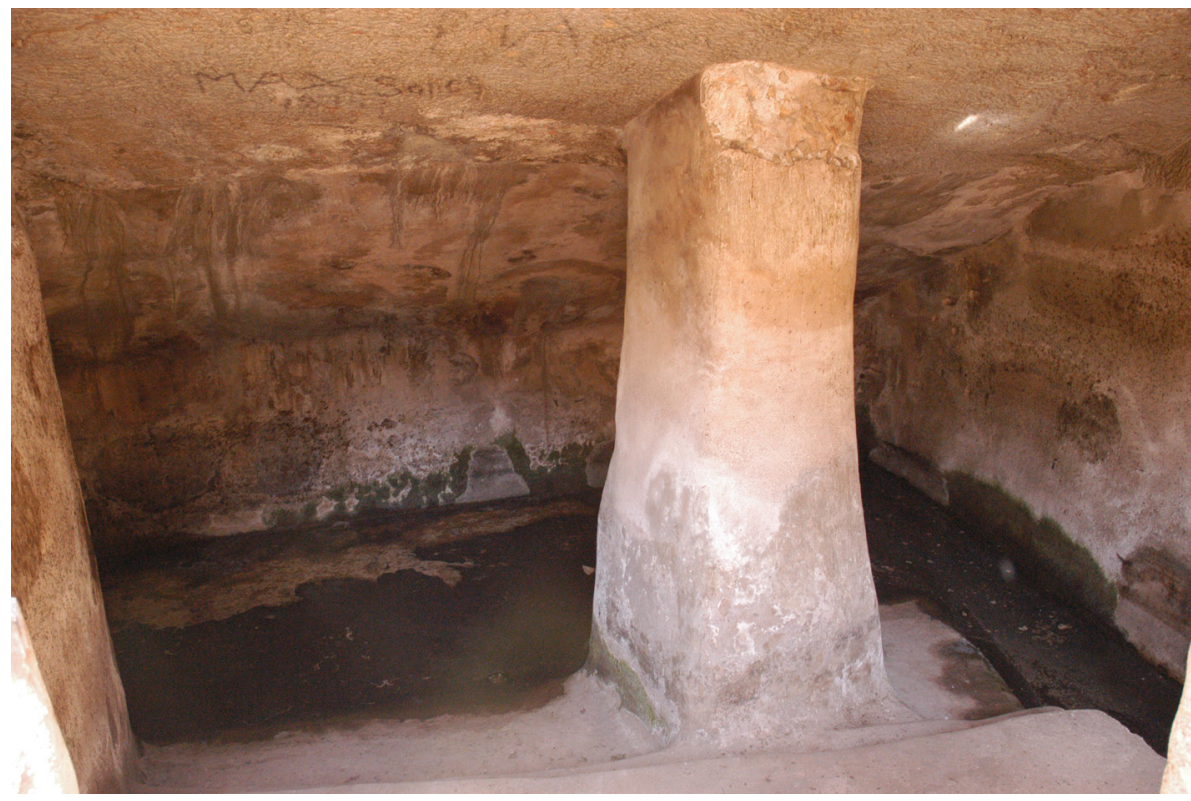

Fig. 5. Ritual bath B, looking east (Photo by A. Graicer) 


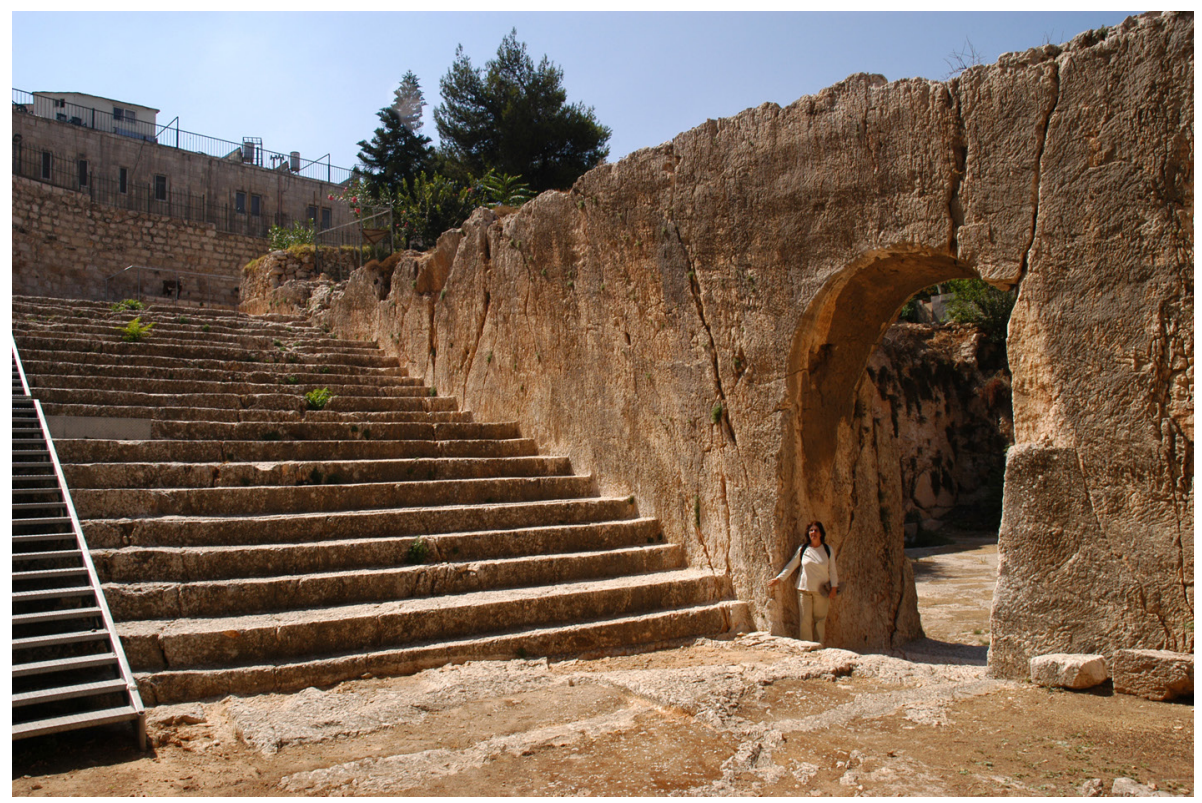

Fig. 6. Monumental staircase and arched gate to courtyard, looking west (Photo by A. Graicer)

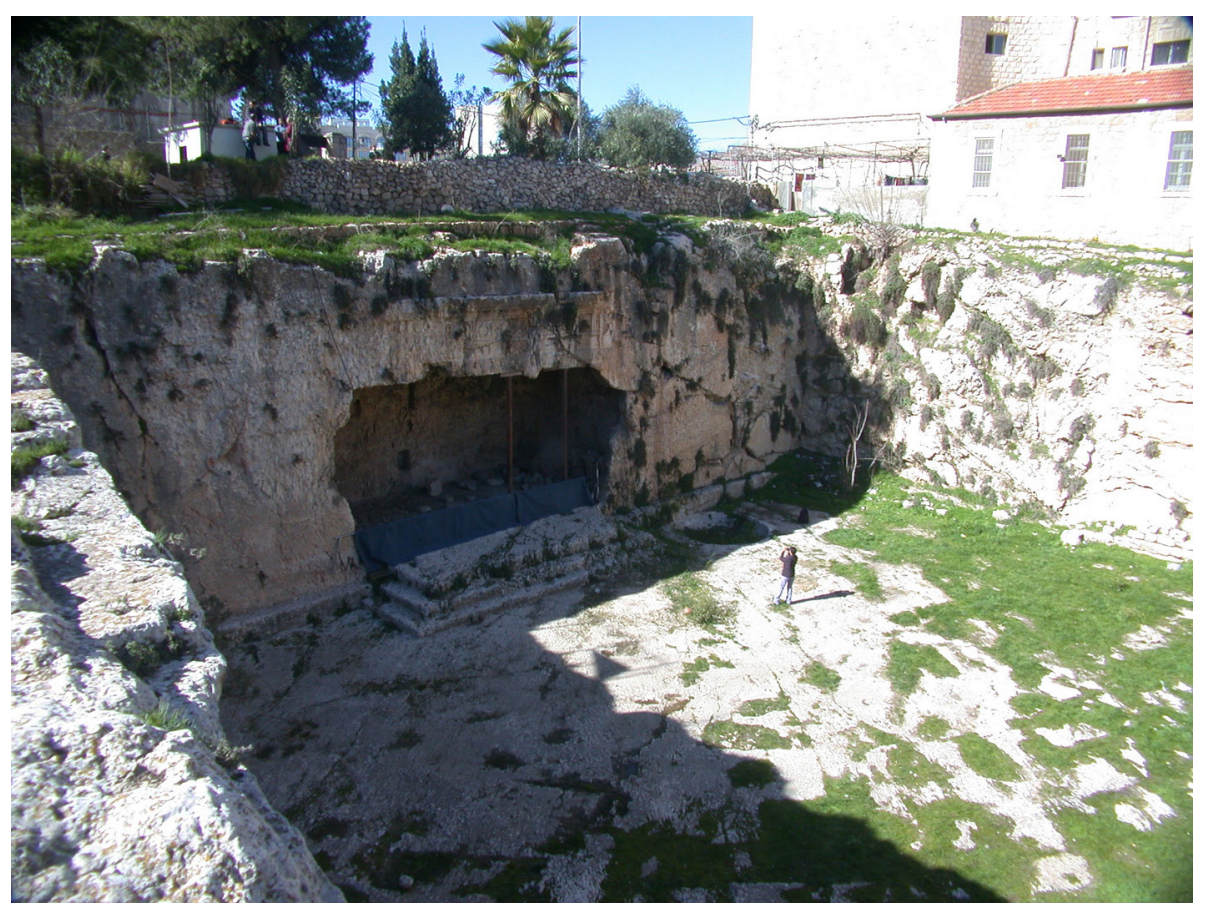

Fig. 7. Tombs of the Kings, courtyard, looking west (Photo by B. Zissu) 
In this paper we reconsider the original purpose of the two ritual baths in the burial compound, based on the location of the site relative to its surroundings.

\section{Scholarship Regarding Ritual Baths Next to Cemeteries}

Despite the large number of ritual baths from the late Second Temple period that have been found, ritual baths next to tombs are fairly rare; so far only 20-30 such sites have been found in the entire country. ${ }^{2}$ Their existence is particularly challenging, and many scholars have discussed the subject due to an apparent conflict between the finds and the Jewish sources.

The basic assumption of the scholars, that the ritual bath served to purify visitors to the gravesite, is problematic because according to the Bible (Leviticus 22: 4-7) and rabbinic law, purification after being in the presence of a dead body requires a seven day process that includes the sprinkling of purification water on the third and seventh days, and is complete only after immersion on the seventh day. ${ }^{3}$ Therefore, immersing in a ritual bath immediately after leaving the burial cave would accomplish nothing from a halachic standpoint because the impurity resulting from being in the presence of the deceased would remain.

Scholars have suggested various solutions to the conundrum. The German theologian Emil Pfennigsdorf proposed that the baths were used to wash the bodies before burial. ${ }^{4}$ Esther Eshel proposed, based on passages from the Dead Sea Scrolls, that they were used by people who followed an extra stringency requiring immersion on the first day of the purification process as well. ${ }^{5}$ Eyal Regev maintained that the baths were evidence of how widespread insistence on "non-priestly purity" was: people would immerse after visiting a grave before engaging in sacred acts such as Torah study, prayer, and eating ordinary, non-sacred food. ${ }^{6}$ Zeev and Hannah Safrai suggested that the ritual baths had to do with a folk custom that existed at the time, similar to the ritual washing of hands when leaving a cemetery mentioned in the Geonic literature. ${ }^{7}$ Finally, Yonatan Adler proposed a halachic solution based on the Bible and rabbinic literature: that ritual baths next to tombs were intended for people with a type of impurity known as tum'at erev (literally, "evening impurity"). ${ }^{8}$ These people had not personally been in the presence of the dead body; rather, they had come in contact with others who had been in the presence of the body. They could immerse immediately after becoming impure and would become pure at sunset. ${ }^{9}$

All these scholars assumed that the ritual baths next to tombs were intended for use solely, or at least primarily, by participants in funerals or memorial ceremonies. They then tried to find one reason for all the ritual baths next to tombs, irrespective of time

Adler 2011, 97.

3 E.g., Numbers 19: 11-22; Sifre Numbers 121, p. 167.

4 Pfennigsdorf 1904, 183-184.

Eshel 1997; Eshel 1999.

6 Regev 2000.

Safrai - Safrai 2004, 414-416.

Sifre Numbers 130, p. 168.

9 Adler 2009; Adler 2011, 121-123. 
period, geography, or physical properties (e.g., the size of the bath). Here we will not argue that all the baths were installed next to tombs for the same reason. Instead we suggest that in the particular case of the Tombs of the Kings, the adjacent baths were not intended for use specifically by participants in the funeral. They were meant for pilgrims to Jerusalem, as can be understood if we look at their geographical location.

\section{Description and Analysis of the Burial Structure}

Before we develop this idea, we have to describe the structure of the ornate burial cave and analyze the division of the compound into separate units.

The complex of the Tombs of the Kings/monument of Helena is divided into two main spatial units. The first is the entrance area: a wide, rectangular corridor leading from an entrance gate that has not survived to a rock-cut plaza via a monumental staircase. The staircase, fashioned expertly by a craftsman, consists of alternating steps with shallow and deep treads. These steps resemble the ones unearthed in the stepped street in the City of David and in the Southern Wall plaza; another example has been found at the entrance to the Cave of Jehoshaphat, which is next to the monument known as Absalom's Pillar. What all these examples have in common is the connection with ceremony, as well as a connection to the Temple.

At the bottom of the stairs are the mouths of the ritual baths described below, one straight across the plaza and the other to the right; to the left, on the northern side, is a gate leading to the tomb courtyard. The gate has an arched lintel and measures $4.55 \mathrm{~m}$ high by 2.9 m wide. ${ }^{10}$ The tomb courtyard, which is carved out of the ground, is particularly spacious: $27.4 \mathrm{~m}$ long and $25.8 \mathrm{~m}$ wide. Along almost the entire perimeter of the tomb courtyard, with the exception of the eastern wall, is a rock-cut bench for visitors and participants in funerals to sit on.

The courtyard and the burial cave to which it leads form the second unit in the complex. The cave façade was adorned, and the ceiling was supported by ornate pillars. According to Maximilian Kon's reconstruction based on Josephus (Antiquities 20.95), three stone pyramids were built on top of the façade; several archaeological finds may confirm this. ${ }^{11}$

The two units are separated by a wall carved out of the matrix with a single opening linking them; this detail helped us realize that the baths are not necessarily directly related to the burial cave.

\section{Description of the Ritual Baths}

As stated, two large ritual baths were carved out of the bedrock at the bottom of the monumental staircase. The baths were entered via rock-cut, vaulted openings. The eastern bath (Miqweh B), located opposite the staircase, has a double entrance; the southern bath

\footnotetext{
10 Kon 1947, 38.

11 Kon 1947, 73-80.
} 
(Miqweh A), to the right of the staircase, has only a single entrance. In addition to having a double entrance, Bath B is divided inside by means of a rock-cut pillar that serves as both a supporting column and a means of separating the two parts of the bath. Each bath has a staircase extending the entire width of the installation down to the pool floor, and in both cases the entire staircase is arranged in a pattern of two narrow-tread steps of standard height followed by a relatively high step with a deep tread. At the bottom of each staircase, a small step was carved in the corner of the floor to make it easier to walk down. ${ }^{12}$ The installations were coated with hydraulic plaster and fed with rainwater via two large channels carved out of the southern wall of the compound.

Bath B is the largest stepped installation in the Jerusalem area. ${ }^{13}$ It is $7.95 \mathrm{~m}$ long; its maximum width, at the wall opposite the entrance, is $8.4 \mathrm{~m}$; and its depth measured from the floor at the entrance (the threshold) is about $3.6 \mathrm{~m}$. Although Bath A is smaller, its dimensions, too, exceed the norm. It is $5.4 \mathrm{~m}$ long; its maximum width, at the wall opposite the entrance, is $4.6 \mathrm{~m}$; and its maximum depth is $2.25 \mathrm{~m} .{ }^{14}$ The extraordinary size of these installations convinced Adler that the baths were intended to serve a large number of people simultaneously. ${ }^{15}$

To sum up, we see that the entire Tombs of the Kings complex is divided into two separate compounds: The entrance compound, which includes a staircase and two huge ritual baths, and the tomb compound, which includes a courtyard facing the ornate façade of the burial cave. The two compounds are connected by one gate. Therefore, we propose that the two compounds were not necessarily related in terms of their purpose. Although visitors to the tomb would have to pass through the ritual bath compound, not all visitors to the ritual baths would necessarily visit the tomb compound.

\section{The Purpose of the Baths in the Tombs of the Kings Based on an Understanding of Their Location: Tombs and Ritual Baths on the Way to the City}

As we suggested above, the ritual bath compound may have served passersby who wanted to purify themselves and were not interested in visiting the tomb. Why would they have needed these baths? To answer this question, let us look at the geographical location of the tomb (see Map 1). The tomb is located not far from the present-day Old City, and a very short distance - just a few dozen meters - from where the Third Wall is believed to have been in the late Second Temple period. ${ }^{16}$

Josephus refers to the "monuments of Helena" several times in his books. In describing the walls of Jerusalem he mentions the monuments of Queen Helena north of the

12 Reich 2013, 128-129.

13 Reich 2013, 128.

14 Kon 1947, 35-37.

15 Adler 2011, 98.

16 In a Roman polis, the outer walls of the city were surrounded by a narrow strip of land known as the pomerium, where it was forbidden to build houses or tombs without special permission from the authorities: Hope 2009, 136. 
city next to the Third Wall (War 5.147), and in describing the siege of the city by Titus he notes that they were right outside the northern gate of the city: "the Jews suddenly dashed out in immense numbers at a spot called 'the Women's towers,' through the gate facing Helena's monuments" (War 5.55).

Accordingly, the monuments of Helena should be on the road to the city, in close proximity to the city gates. There is nothing surprising about finding tombs next to city gates or along the road to a city. We are familiar with tombs on many main roads leading to Roman and Greek cities, ${ }^{17}$ such as the Via Appia, the Via Labicana, and the Via Flaminia in Rome; the Via Consolare in Pompeii; the Wadi Siq road to Nabatean Petra; and the Panathenaic Way in Athens. Recently the first author suggested that there were tombs next to at least one main road in Jerusalem in that period - the route passing from Nahal Kidron toward the southern gate at the foot of the City of David. ${ }^{18}$ The reason for placing tombs and burial monuments on the roadside was to achieve maximum visibility and easy access, so that all passersby would see the tomb and the deceased would be memorialized in a more dignified manner. ${ }^{19}$

Moreover, the rabbis allude to the presence of tombs along roads taken by the pilgrims to Jerusalem: "On the fifteenth thereof ... the roads, open spaces, and ritual baths are repaired, all public needs are taken care of, and the graves are marked" (M Shekalim 1:1). This mishnah talks about both marking graves and repairing roads as part of the preparations for the pilgrimage. The Tosefta, too, emphasizes the proximity of tombs to the road: "On the fifteenth thereof, emissaries of the court go out and mark the place of impurity so that the people will not find themselves in it" (T Shekalim 1:1).

According to the rabbis, graves were not the only things alongside the road; there were also various water installations for drinking and purification purposes. Consequently, David Amit proposed that the pair of big ritual baths that he had excavated near Alon Shevut were part of an array of ritual baths installed for the benefit of pilgrims on their way to Jerusalem..$^{20}$ This suggestion is based on the location of the baths in an open area far from any populated place, adjacent to the route of the Roman road, near where a milestone was found. According to Amit, this site and the site of the huge Bir Ijda ritual bath near Elonei Mamre were spots where pilgrims to Jerusalem would camp and could use the public ritual purification facilities. ${ }^{21}$

Pursuant to Amit's proposal, we suggest that the two large ritual baths in the Tombs of the Kings, too, were intended to serve pilgrims on their way to Jerusalem and during their stay in the city. ${ }^{22}$ This suggestion is based first on the exceptional size of the baths (Bath B is probably the largest ritual bath in Jerusalem), and second, on the proximity of

17 Carroll 2006, 48; Hope 2009, 154-156.

18 Abadi 2016.

19 Carroll 2006, 48; Hope 2009, 155.

20 Amit 1999.

21 Yonatan Adler $(2011,121-123)$ subsequently further developed this idea.

22 Pilgrims were required to immerse not only before entering the Temple but also before eating sacrificial offerings in Jerusalem outside the Temple grounds (such as the Passover offering and the thanksgiving offering), and before eating the second tithe (e.g., M Ma'aser Sheni 3:9-10). Hence even while they were in the city pilgrims had to immerse several times. Whoever did not have friends or acquaintances in the city could use public ritual baths, such as the ones at the Tombs of the Kings, just a short walk from the city gate. 
these installations to the road and to the city north gate. Another large sized ritual bath (c. $4.5 \times 6 \mathrm{~m}$ ) with a double entrance, situated next to an ancient road and in the vicinity of tombs was documented by the second author on Shemuel Hanavi Street in Jerusalem (Zissu 1994).

\section{Queen Helena's Source of Inspiration}

Despite our suggestion, the combination of ritual baths and tombs along the road seems really odd. Why would a ritual purification facility for the public be inside a family tomb compound? ${ }^{23}$ In searching for parallels elsewhere we came up empty-handed. Nevertheless, we do find many examples in the Roman world of installations built alongside roadside tombs for the convenience of passersby: benches to rest on, gardens for beauty, and even shops and stalls. ${ }^{24}$ The idea was to provide services to users of the road in order to memorialize the person buried there. This idea-though in a more Jewish form - seems to fit the monument to Helena. Instead of a bench, shop, or garden, a ritual bath was installed next to the tomb for the use of Jews making a pilgrimage to Jerusalem. Thus Queen Helena not only aided the pilgrims but also perpetuated her own memory and caused many passersby — whether or not they had ever heard of her - to visit her grave.

This contribution by Queen Helena and her sons is not surprising. The family's philanthropy is mentioned many times by the rabbis (e.g., T Peah 4: 18; BT Yoma 37a) and by Josephus. Josephus describes how Queen Helena helped the local people during a famine (Antiquities 20.50-53), and the rabbis mention the family's many contributions to the Temple: "King Monobaz [or Molobaz] made all the handles of the vessels for the Day of Atonement out of gold. His mother Helena made a golden candlestick over the door to the heikhal. She also made a golden tablet on which the passage about the suspected adulteress was written" (M Yoma 3:10).

The designers of the ritual baths evidently had the Temple Mount and Temple in mind, given that the staircase leading down to them is identical in plan to the staircase that ascended from the City of David to the entrance gates to the Temple Mount from the south. Therefore, if the scholars' identification is correct and this is indeed Queen Helena's tomb, the stories of her connection and that of her sons to the Temple make it more likely that they built these baths for pilgrims visiting the Temple, thereby giving to the Temple and to the entire Jewish people even in grief and death.

Helena had been the queen of Adiabene, on the Armenian border. After converting to Judaism, she moved to Jerusalem and gave generously to the Jewish people and the Temple. She then returned to her country of birth, Adiabene, where she passed away during the 50s. ${ }^{25}$ After her death her son Monobaz brought her remains to Jerusalem for burial, and he memorialized his mother and her heritage with a burial plot that would remind

23 For now, we will not discuss the subject of impurity in the tomb and the purity of the ritual bath, since that would take us outside the purview of this paper.

24 Carroll 2003; Graham 2005; Carroll 2006, 49-50.

25 Jos. AJ 20.17-96; Schifffmann 1982; Safrai 2009/2010, 131-132. 
all passersby of her philanthropic character. To accomplish this, he not only gave her an ornate tombstone as befits a queen, but also built something that reflected his mother's passion for the Temple and her generosity to it: huge ritual baths adjacent to her tomb to be used, at no cost, by anyone who wanted to rejoice in the Temple on the festivals in a state of purity.

BIBLIOGRAPHY

Abadi, O. (2016), The Pilgrims' Road to Jerusalem in the Second Temple Period: A Cultural-Archaeological Perspective, in: G. Stiebel, D. Amit (eds.), New Studies in the Archaeology of Jerusalem and Its Region, Jerusalem (Hebrew).

Adler, Y. (2009), Ritual Baths Adjacent to Tombs: An Analysis of the Archaeological Evidence in Light of the Halakhic Sources, Journal of the Study of Judaism 40: 55-73.

Adler, Y. (2011), Archaeological Evidence for the Observance of Ritual Purity in Erez-Israel from the Hasmonean Period until the End of the Talmudic Era (164 BCE-400 CE), Diss. Bar-Ilan University (Hebrew).

Amit, D. (1999), A Miqveh Complex near Alon Shevut, 'Atiqot 38: 75-84.

Carroll, M. (2003), Earthly Paradises: Ancient Gardens in History and Archaeology, London.

Carroll, M. (2006), Spirits of the Dead: Roman Funerary Commemoration in Western Europe, New York.

Eshel, E. (1997), 4Q414 Fragment 2: Purification of a Corpse-Contaminated Person, in: M. Bernstein, F. G. Martinez, J. Kampen (eds.), Legal Texts and Legal Issues: Proceedings of the Second Meeting of the International Organization for Qumran Studies, Cambridge: 3-10.

Eshel, E. (1999), 4QRitual of Purification A, in: J. Baumgarten (ed.), Qumran Cave 4, XXV: Halakhic Texts, Oxford: 54-135.

Graham, E. J. (2005), The Quick and the Dead in the Extra-Urban Landscape: The Roman Cemetery at Ostia/Portus as a Lived Environment, in: J. Bruhn, B. Croxford, D. Grigoropoulos (eds.), Proceedings of the Fourteenth Annual Theoretical Roman Archaeology Conference, Oxford: $133-143$.

Hope, V. M. (2009), Roman Death: The Dying and Death in Ancient Rome, London.

Josephus, Jewish Antiquities, Book 20, translated by L. H. Feldman, Harvard University Press, 1965.

Josephus, The Jewish War, translated by H. S. J. Thackeray, London 1926, https://archive.org/details/ josephuswitheng103joseuoft.

Kloner, A., Zissu, B. (2007), The Necropolis of Jerusalem in the Second Temple Period, Leuven-Dudley, MA.

Kokkinos, N. (2015), Aspects of Jerusalem under Herod, Eretz-Israel 31: 79-109.

Kon, M. (1947), The Tombs of the Kings, Tel Aviv (Hebrew).

Pfennigsdorf, E. (1904), Die Aussenanlagen der sog. Königsgräber (kubūr es-salātīn) bei Jerusalem, Zeitschrift des Deutschen Palästina-Vereins 27: 86-173.

Regev, E. (2000), Pure Individualism: The Idea of Non-Priestly Purity in Ancient Judaism, Journal of the Study of Judaism 31: 176-202.

Reich, R. (2013), Miqwa'ot in the Second Temple, Mishnaic and Talmudic Periods, Jerusalem (Hebrew).

Safrai, Z. (2009/2010), Mishnat Eretz Israel: Tractate Yoma, Jerusalem (Hebrew).

Safrai, Z., Safrai, C. (2004), Were the Sages a Ruling Elite?, in: D. Gera, M. Ben Zeev (eds.), The Path of Peace: Studies in Honor of Israel Friedman Ben-Shalom, Beersheva: 373-440 (Hebrew). 
Schiffman, Y. (1982), Conversion in the Writings of Josephus: Izates of Adiabene in Light of Jewish Law, in: U. Rappaport (ed.), Josephus Flavius: Historian of Eretz-Israel in the Hellenistic-Roman Period, Jerusalem: 247-265 (Hebrew).

Sifre Numbers = Siphre d'Be Rab, 1917, vol. 1: Sifre on the Book of Numbers and Sifre Zuta with Alternative Versions and Notes, ed. H. S. Horovitz, Leipzig (Hebrew).

Stern, E. (ed.) (1992), The New Encyclopedia of Archaeological Excavations in Eretz Israel, Jerusalem (Hebrew).

Zissu, B. (1994), Jerusalem, Shemuel Hanavi Street, Excavations and Surveys in Israel 14: 144. 